\title{
Changes in Air Quality from the COVID to the Post-COVID Era in the Beijing-Tianjin-Tangshan Region in China
}

Special Issue:

Special Issue on Air Quality in a Changed World: Regional, Ambient, and Indoor Air Concentrations from the COVID to Post-COVID Era (I)

\section{OPEN ACCESS}

Received: October 5, 2021

Revised: November 20, 2021

Accepted: November 23, 2021

\section{* Corresponding Authors: \\ Qingchun Guo \\ guoqingchun@lcu.edu.cn \\ Zhaosheng Wang \\ wangzs@igsnrr.ac.cn}

\section{Publisher:}

Taiwan Association for Aerosol Research

ISSN: $1680-8584$ print

ISSN: 2071-1409 online

\section{Copyright: The Author(s).}

This is an open access article distributed under the terms of the Creative Commons Attribution License (CC BY 4.0), which permits unrestricted use, distribution, and reproduction in any medium, provided the original author and source are cited.

\section{Qingchun Guo ${ }^{1,2^{*}}$, Zhaosheng Wang ${ }^{3}$, Zhenfang $\mathrm{He}^{1,4}$, Xinzhou $\mathrm{Li}^{2,5}$, Jingjing Meng ${ }^{1}$, Zhanfang Hou $^{1}$, Jiaoxue Yang ${ }^{1}$}

${ }^{1}$ School of Geography and the Environment, Liaocheng University, Liaocheng 252000, China ${ }^{2}$ State Key Laboratory of Loess and Quaternary Geology, Institute of Earth Environment, Chinese Academy of Sciences, Xi'an 710061, China

${ }^{3}$ National Ecosystem Science Data Center, Key Laboratory of Ecosystem Network Observation and Modeling, Institute of Geographic Sciences and Natural Resources Research, Chinese Academy of Sciences, Beijing 100101, China

${ }^{4}$ State Key Laboratory of Urban and Regional Ecology, Research Center for Eco-Environmental Sciences, Chinese Academy of Sciences, Beijing 100085, China

${ }^{5}$ CAS Center for Excellence in Tibetan Plateau Earth Sciences, Beijing 100101, China

\section{ABSTRACT}

This article discussed air quality changes in the Beijing-Tianjin-Tangshan (BTT) region. The air quality index (AQI) values, and the concentrations of $\mathrm{PM}_{2.5}, \mathrm{PM}_{10}, \mathrm{SO}_{2}, \mathrm{CO}, \mathrm{NO}_{2}$, and $\mathrm{O}_{3}$ in the $\mathrm{BTT}$ region during the COVID-19 outbreak in 2020 were, respectively, 79.4, $47.2 \mu \mathrm{g} \mathrm{m}^{-3}, 73.4 \mu \mathrm{g} \mathrm{m}^{-3}$, $10.3 \mu \mathrm{g} \mathrm{m}^{-3}, 0.87 \mathrm{mg} \mathrm{m}^{-3}, 33.6 \mu \mathrm{g} \mathrm{m}^{-3}$, and $90.7 \mu \mathrm{g} \mathrm{m}^{-3}$. However, they were, respectively, 102.7, $61.4 \mu \mathrm{g} \mathrm{m}^{-3}, 121.0 \mu \mathrm{g} \mathrm{m}^{-3}, 9.0 \mu \mathrm{g} \mathrm{m}^{-3}, 0.88 \mathrm{mg} \mathrm{m}^{-3}, 40.1 \mu \mathrm{g} \mathrm{m}^{-3}$, and $84.0 \mu \mathrm{g} \mathrm{m}^{-3}$ during the same period in 2021 , which is an increase of $29.2 \%, 30.1 \%, 64.8 \%,-12.9 \%, 1.94 \%, 19.5 \%$, and $-7.4 \%$ compared with the values in 2020 . The combined proportions of grade I and grade II during the COVID-19 outbreak in 2020 were $16.7 \%$ higher than those in the same period in 2021, so the air quality has deteriorated rapidly from 2020 to the post-COVID era in 2021. The possible reasons for poorer air quality are that the frequency of dusty weather and air pollutant discharge has increased, and meteorological conditions have been relatively unfavorable. The average AQI values, and concentrations of $\mathrm{PM}_{2.5}, \mathrm{PM}_{10}, \mathrm{SO}_{2}, \mathrm{CO}, \mathrm{NO}_{2}$, and $\mathrm{O}_{3}$ during the post-COVID period in 2021 respectively decreased by $14.8 \%, 29.0 \%, 14.6 \%, 22.5 \%, 37.4 \%, 14.8 \%$, and $8.7 \%$, compared with those in 2020. It is also worth noting that all the changes in air pollution during the post-COVID era have been consistent. The combined proportions of grade I and grade II during post-COVID period in 2021 were $18.4 \%$ higher than those during the same period of 2020, which indicates that the air quality during post-COVID 2021 has obviously improved compared with those in the same period of 2020. The possible reasons are a series of clean air policies and clean air actions, as well as favorable atmospheric diffusion conditions. These results indicate that clean air policies play a very important role in improving air quality.

Keywords: COVID-19, Post-COVID, Air quality, $\mathrm{PM}_{2.5}, \mathrm{PM}_{10}$

\section{INTRODUCTION}

Up to November 14, 2021 globally, over 5, 092, 761 people have died, and 252, 826, 597 have been infected with COVID-19 (WHO). Efforts to control COVID-19 transmission have greatly reduced human social and economic activities worldwide. The Chinese government launched a lockdown campaign on January 23, 2020. China closed business activities, restricted travel and required people to stay at home starting in late January of 2020 (Guo and He, 2021). These prevention 
and control actions are related to the air pollution during that period.

Air pollution has a harmful influence on human health, the climate, and sustainable development (Guo et al., 2020). The COVID-19 pandemic has affected air quality due to changes in human behavior (He et al., 2020; Huang et al., 2020; Le et al., 2020). In 2020, travel restrictions in many cities in China greatly reduced air pollution emissions. The average air quality index (AQI) decreased by $7.80 \%$, and average concentrations of $\mathrm{PM}_{2.5}, \mathrm{SO}_{2}, \mathrm{NO}_{2}, \mathrm{PM}_{10}$, and $\mathrm{CO}$ decreased by $5.9 \%, 6.8 \%$, $24.7 \%, 13.7 \%$, and $4.6 \%$, respectively (Bao and Zhang, 2020). The $\mathrm{PM}_{2.5}$ values in Shanghai, Beijing, Wuhan and Guangzhou during the COVID-19 period were analyzed. It was found that air pollution was significantly reduced because of the decrease in transportation and industrial emissions (Wang et al., 2020a). Variation in $\mathrm{PM}_{2.5}$ change from season to season, as well as from month to month, depending on crop residue burning, dust events, human activities, and traffic emissions. Due to the lockdown, $\mathrm{PM}_{2.5}$ in Mumbai and New Delhi fell in March of 2020, much less than in a similar period from 2017-2019. Similar decreases in $\mathrm{PM}_{2.5}$ were observed in Shanghai, Beijing, and Zaragoza. $\mathrm{PM}_{2.5}$ decreased significantly in Los Angeles and New York, in America (Chauhan and Singh, 2020). During COVID-19 lockdown, the concentrations of $\mathrm{NO}_{2}, \mathrm{PM}_{10}$, and $\mathrm{SO}_{2}$ in Salé City (Morocco) decreased by more than half (Otmani et al., 2020). With the exception of Yangon City and $\mathrm{Ho}$ Chi Minh City, the level of $\mathrm{NO}_{2}$ in cities in the Southeast Asia region decreased significantly during the COVID-19 period (Kanniah et al., 2020). The concentrations of $\mathrm{PM}_{10}$ and $\mathrm{PM}_{2.5}$ during the lockdown in Delhi decreased in comparison to the period prior to the lockdown, and the CO and $\mathrm{NO}_{2}$ levels also dropped during the lockdown period (Mahato et al., 2020). The lockdown caused by COVID-19 decreased transportation activity and liquidity by $90 \%$. The air quality improved, and $\mathrm{NO}_{2}$ emissions were reduced by 30\% (Muhammad et al., 2020). As a result of the COVID-19 lockdown, $\mathrm{NO}_{2}$ levels in Asian and European countries decreased significantly (Gautam, 2020). Restrictions on human activities during the lockdown have greatly reduced the concentrations of environmental pollutants in China and in the United States (Shakoor et al., 2020).

Due to the outbreak of COVID-19, nearly half of the world is partially or completely locked down, resulting in industrial and motor vehicle downtime and a corresponding reduction of atmospheric pollutant concentrations. From January 2020 to March 2020, the global concentrations of $\mathrm{NO}_{2}$ decreased sharply (Lal et al., 2020). The prevalence of COVID-19 has thus had a great impact on air quality. The possible reason for this is that in the course of epidemic prevention, industrial production and transportation activities were greatly restricted and reduced, leading to a quick reduction in the emission of air pollutants (Xu et al., 2020a).

Air pollution is very serious in northern cities in winter, and the " $2+26$ " cities are the transmission channels of Beijing-Tianjin-Hebei air pollution. The Beijing-Tianjin-Tangshan (BTT) region is located in the north of China's eastern coastal zone, and is characterized by a semi-arid continental climate. The Beijing-Tianjin-Tangshan region is the most polluted area in China. In this article, the air pollution in the BTT region, including $\mathrm{PM}_{10}, \mathrm{PM}_{2.5}, \mathrm{SO}_{2}, \mathrm{NO}_{2}, \mathrm{CO}$, and $\mathrm{O}_{3}$, and AQIs from 2013 to 2021 are investigated.

\section{MATERIAL AND METHODS}

From 2013 to 2021, the air pollution in the BTT region, China (Fig. 1), is researched. The AQI values, and the concentrations of $\mathrm{PM}_{10}, \mathrm{PM}_{2.5}, \mathrm{NO}_{2}, \mathrm{SO}_{2}, \mathrm{CO}$, and $\mathrm{O}_{3}$ in the BTT region are investigated (http://www.aqistudy.cn/). These data (2020-2021) are divided into two parts: period I (February 1 to April 30, 2020-2021); period II (May 1 to October 31, 2020-2021). Air pollution emissions data were gathered from the Chinese urban statistical yearbook, and data for meteorological elements were derived from the Meteorological Bureau. The air pollution emissions data included $\mathrm{SO}_{2}$ emissions $\left(\mathrm{SO}_{2} \mathrm{E}\right), \mathrm{NO}_{\mathrm{x}}$ emissions $\left(\mathrm{NO}_{\mathrm{x}} \mathrm{E}\right)$, and particulate matter emissions ( $P M E$ ). The meteorological data included precipitation ( $P$ ), average atmospheric pressure (AAP), average wind speed (AWS), average atmospheric temperature (AAT), average relative humidity $(\mathrm{ARH})$, and sunshine hours $(\mathrm{SH})$.

The AQI is a dimensionless value that quantitatively depicts the air pollution. The daily AQI value is computed using the 24-hour mean concentrations of $\mathrm{PM}_{10}, \mathrm{PM}_{2.5}, \mathrm{CO}, \mathrm{SO}_{2}$, and $\mathrm{NO}_{2}$, and the daily maximum 8-hour concentration of $\mathrm{O}_{3}$ (Xu et al., 2020a). The six air pollution levels are shown in Table 1. 


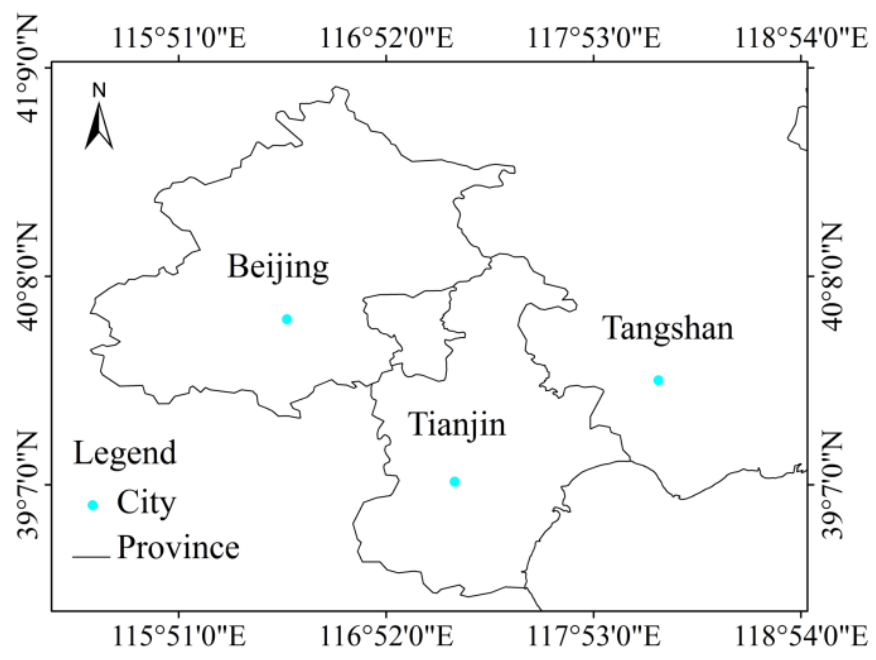

Fig. 1. Location of the Beijing-Tianjin-Tangshan region, China.

Table 1. AQI scope and air quality category.

\begin{tabular}{lll}
\hline AQI value & Grade & category \\
\hline $0-50$ & I & Excellent \\
$51-100$ & II & Good \\
$101-150$ & III & Mild pollution \\
$151-200$ & IV & Moderate pollution \\
$201-300$ & V & Heavy pollution \\
$>300$ & VI & Serious pollution \\
\hline
\end{tabular}

\section{RESULTS AND DISCUSSION}

In 2021, air pollution has varied from that in 2020 because of the COVID-19 outbreak when factories were closed. The Chinese government took advantage of the strictest measures to control the spread of the COVID-19 virus. These measures were put in place on January 23, 2020. After January 25, 2020, this control was enforced for about 3 months, when travel was restricted, after which factories gradually began operations after a long delay. In the present study, firstly, the air quality from 2013 to 2020 is analyzed, and then changes in air quality from the COVID to the post-COVID era in the Beijing-Tianjin-Tangshan region are analyzed and discussed.

\subsection{Long-term Changes in Air Quality over the Beijing-Tianjin-Tangshan Region}

As shown in Fig. 2, the air quality in the BTT region gradually improved on an annual basis. The values of $\mathrm{PM}_{2.5}, \mathrm{PM}_{10}, \mathrm{NO}_{2}$ and $\mathrm{SO}_{2}$, in the $\mathrm{BTT}$ region in 2013 were, respectively, $100.2 \mu \mathrm{g} \mathrm{m}^{-3}$, $147.4 \mu \mathrm{g} \mathrm{m}^{-3}, 59.7 \mu \mathrm{g} \mathrm{m}^{-3}$, and $66.5 \mu \mathrm{g} \mathrm{m}^{-3}$. The AQI values and levels of $\mathrm{CO}$, and $\mathrm{O}_{3}$ in 2014 were, respectively, $128.1,1.77 \mathrm{mg} \mathrm{m}^{-3}$, and $91.5 \mu \mathrm{g} \mathrm{m}^{-3}$. However, they were, respectively, $44.9 \mu \mathrm{g} \mathrm{m}^{-3}$, $71.9 \mu \mathrm{g} \mathrm{m}^{-3}, 38.1 \mu \mathrm{g} \mathrm{m}^{-3}, 10.2 \mu \mathrm{g} \mathrm{m}^{-3}, 86.6,0.91 \mathrm{mg} \mathrm{m}^{-3}$, and $97.8 \mu \mathrm{g} \mathrm{m}^{-3}$ in 2020 . Thus, the values in 2020 were $60.9 \%, 54.5 \%, 38.1 \%, 118.8 \%, 32.4 \%, 49.0 \%$, and $6.9 \%$, lower than those in 2013 and 2014. Air quality in 2020 was obviously better than that in 2013. Compared with the Yangtze River Delta, air pollution in the Beijing-Tianjin-Hebei region in 2019-2020 was more serious (Wang et al., 2021).

\subsection{The Relationship between the Long-term Change in Air Quality, Air Pollution Emissions, and Meteorological Conditions}

Air quality is mainly affected by air pollution emissions and meteorological conditions. In 2013, China began to significantly promote actions by which to control air pollution. In 2013, China publicly released an action plan for air pollution prevention and control, and in 2018, China issued 


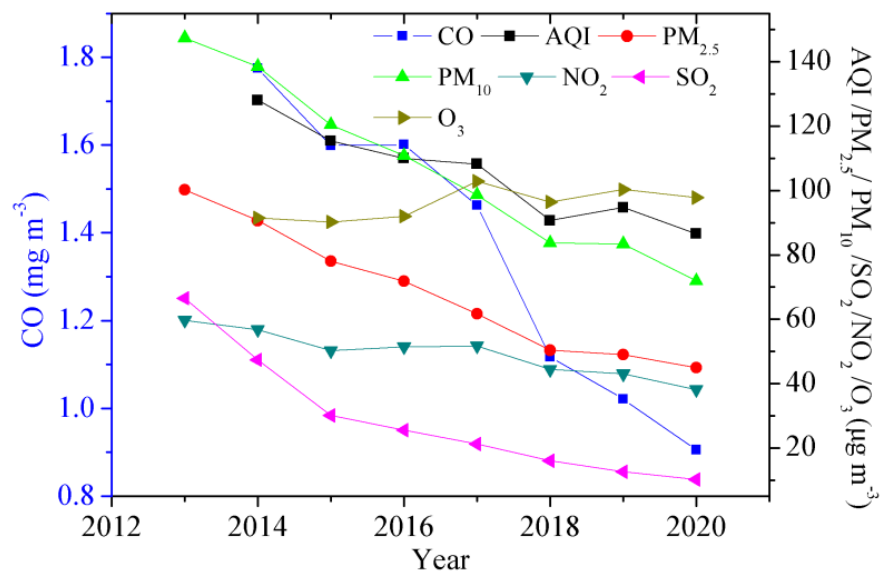

Fig. 2. Variations in air quality from 2013 to 2020.

Table 2. Correlation coefficients between air quality, air pollution emissions, and meteorological elements.

\begin{tabular}{llllllllll}
\hline & $\mathrm{SO}_{2} \mathrm{E}$ & $\mathrm{NO}_{x} \mathrm{E}$ & $\mathrm{PM} \mathrm{E}$ & $\mathrm{P}$ & $\mathrm{AAP}$ & $\mathrm{AWS}$ & $\mathrm{AAT}$ & $\mathrm{ARH}$ & $\mathrm{SH}$ \\
\hline $\mathrm{AQI}$ & $0.915^{*}$ & 0.872 & $0.917^{* *}$ & -0.165 & -0.235 & -0.406 & $0.320^{* *}$ & 0.626 & -0.916 \\
$\mathrm{CO}$ & $0.848^{*}$ & $0.801^{* *}$ & 0.918 & 0.066 & -0.259 & $-0.167^{* *}$ & 0.224 & 0.629 & $-0.881^{* *}$ \\
$\mathrm{O}_{3}$ & -0.735 & -0.671 & -0.854 & -0.279 & -0.244 & 0.134 & 0.563 & -0.819 & 0.655 \\
$\mathrm{PM}_{2.5}$ & $0.959^{* *}$ & $0.941^{* *}$ & $0.916^{* *}$ & -0.139 & -0.637 & $-0.022^{* *}$ & $-0.536^{* *}$ & 0.795 & $-0.934^{* *}$ \\
$\mathrm{PM}_{10}$ & $0.966^{* *}$ & $0.946^{* *}$ & $0.923^{* *}$ & -0.177 & $-0.621^{* *}$ & -0.042 & $-0.498^{* *}$ & $0.760^{* *}$ & -0.927 \\
$\mathrm{NO}_{2}$ & $0.854^{*}$ & $0.857^{*}$ & $0.811^{*}$ & -0.13 & $-0.662^{* *}$ & $0.086^{* *}$ & -0.403 & $0.592^{* *}$ & $-0.847^{* *}$ \\
$\mathrm{SO}_{2}$ & $0.901^{* *}$ & $0.928^{* *}$ & $0.779^{*}$ & -0.21 & $-0.798^{* *}$ & $0.032^{* *}$ & $-0.682^{* *}$ & $0.730^{* *}$ & $-0.857^{* *}$ \\
\hline
\end{tabular}

** represents a significance level of 0.01 .

* represents a significance level of 0.05 .

a three-year action plan for winning the blue sky defense war. With the implementation of the clean air policy in the BTT region, significant declines in the $A Q I$ values and those of $\mathrm{PM}_{2.5}, \mathrm{PM}_{10}$, $\mathrm{SO}_{2}, \mathrm{CO}, \mathrm{NO}_{2}$, and $\mathrm{O}_{3}$ occurred from 2013 to 2020. As shown in Table 2, the correlation coefficients between air quality and air pollution emissions were relatively high. Air quality (AQI values and concentrations of $\mathrm{PM}_{2.5}, \mathrm{PM}_{10}, \mathrm{SO}_{2}, \mathrm{CO}$, and $\mathrm{NO}_{2}$ ) was shown to be positively correlated with air pollution emissions $\left(\mathrm{SO}_{2}, \mathrm{NO}_{x}\right.$, and $\left.\mathrm{PM}\right)$, while $\mathrm{O}_{3}$ was negatively correlated with air pollution emissions. Beijing is a VOC-limited city with a lower $\mathrm{VOC} / \mathrm{NO}_{\mathrm{x}}$ ratio; in order to alleviate $\mathrm{O}_{3}$ pollution, emissions of VOCs should be controlled (Li et al., 2021).

Air quality (AQI values and concentrations of $\mathrm{PM}_{2.5}, \mathrm{PM}_{10}, \mathrm{SO}_{2}, \mathrm{CO}, \mathrm{NO}_{2}$, and $\mathrm{O}_{3}$ ) was negatively correlated with the average atmospheric pressure (AAP). $\mathrm{PM}_{2.5}$ was negatively correlated with precipitation ( $P$ ), average wind speed (AWS), average atmospheric temperature (AAT), and sunshine hours $(\mathrm{SH})$, and was positively correlated with the average relative humidity $(\mathrm{ARH}) . \mathrm{O}_{3}$ was negatively correlated with precipitation $(P)$, and the average relative humidity (ARH), and positively correlated with the average wind speed (AWS), the average atmospheric temperature (AAT), and sunshine hours (SH). Favorable meteorological conditions can thus improve air quality.

During the COVID-19 lockdown period, the uninterrupted industrial emissions and smoke in the surrounding areas and adverse meteorological conditions may be the reason for the abnormally high concentration of $\mathrm{PM}_{2.5}$ in Beijing (Gao et al., 2021). $\mathrm{PM}_{2.5}$ levels increased from the summer of 2019 to 2020. The increase in $\mathrm{PM}_{2.5}$ is the outcome of the enhancement of the secondary formation process indicated by the higher sulfate oxidation rate (SOR) and higher nitrate oxidation rate (NOR) in 2020. Higher SOR and NOR are mainly due to higher relative humidity and stronger oxidation capacity (Li et al., 2021). The reason for severe haze in Beijing-Tianjin-Hebei during the COVID-19 lockdown is that the increased $\mathrm{PM}_{2.5}$ concentration under adverse meteorological conditions was greater than the reduced $\mathrm{PM}_{2.5}$ concentration under the emissions reduction conditions (Zhang et al., 2021). 


\subsection{Comparison of Air Pollution between the COVID and Post-COVID Era in the BTT Region}

The average daily air pollutant concentrations and AQI values in the BTT region, from February 1 to April 30, 2020-2021 are shown in Table 3. The AQI values and concentrations of $\mathrm{PM}_{2.5}, \mathrm{PM}_{10}, \mathrm{SO}_{2}$, $\mathrm{CO}, \mathrm{NO}_{2}$, and $\mathrm{O}_{3}$ in the $\mathrm{BTT}$ region were, respectively, 79.4, $47.2 \mu \mathrm{g} \mathrm{m}^{-3}, 73.4 \mu \mathrm{g} \mathrm{m}^{-3}, 10.3 \mu \mathrm{g} \mathrm{m}^{-3}$, $0.87 \mathrm{mg} \mathrm{m}^{-3}, 33.6 \mathrm{\mu g} \mathrm{m}^{-3}$, and $90.7 \mu \mathrm{g} \mathrm{m}^{-3}$ during the COVID in 2020 and were, respectively, 102.7, $61.4 \mu \mathrm{g} \mathrm{m}^{-3}, 121.0 \mu \mathrm{g} \mathrm{m}^{-3}, 9.0 \mu \mathrm{g} \mathrm{m}^{-3}, 0.88 \mathrm{mg} \mathrm{m}^{-3}, 40.1 \mu \mathrm{g} \mathrm{m}^{-3}$, and $84.0 \mu \mathrm{g} \mathrm{m}^{-3}$ during the same period in 2021. Compared with the same values during the COVID outbreak in 2020, the values in 2021 increased by $23.2,14.2 \mu \mathrm{g} \mathrm{m}^{-3}, 47.6 \mu \mathrm{g} \mathrm{m}^{-3},-1.3 \mu \mathrm{g} \mathrm{m}^{-3}, 0.02 \mathrm{mg} \mathrm{m}^{-3}, 6.6 \mu \mathrm{g} \mathrm{m}^{-3}$, and $-6.7 \mu \mathrm{g} \mathrm{m}^{-3}$; which was $29.2 \%, 30.1 \%, 64.8 \%,-12.9 \%, 1.94 \%, 19.5 \%$, and $-7.4 \%$ higher in 2021 than in 2020. However, these three cities have remarkable differences. The $\mathrm{SO}_{2}$ concentration decreased in Beijing and Tangshan, but increased in Tianjin. The CO concentration increased in Beijing and Tianjin, but decreased in Tangshan. It is worth mentioning that the change in the $\mathrm{O}_{3}$ concentration is in inverse proportion to the changes in the other values. The formation of $\mathrm{O}_{3}$ in the Chinese cities mostly originates from an $\mathrm{NO}_{x}\left(\mathrm{NO}\right.$ and $\mathrm{NO}_{2}$ )-saturated state because there are few $\mathrm{HO}_{\mathrm{x}}$ radicals in winter (Steinfeld, 1998). Furthermore, the sharp reduction in $\mathrm{NO}_{2}$ during the lockdown can lead to lower levels of NO (Xu et al., 2020b), which in turn reduces the titration of $\mathrm{O}_{3}$ (Steinfeld, 1998). Hence, a reduction in $\mathrm{NO}_{2}$ led to the enhancement of $\mathrm{O}_{3}$ during the lockdown. The negative relationship between $\mathrm{O}_{3}$ and the $\mathrm{PM}_{2.5}$ mass can be attributed to the aerosol radiative effect on the photochemistry production and the decreased precursors of $\mathrm{O}_{3}$ ( $\mathrm{Li}$ et al., 2019a; Wu et al., 2020). The increase in ozone may have been partly driven by the decrease in $\mathrm{PM}_{2.5}$, where the specific mechanism leading to this phenomenon is the fact that $\mathrm{PM}_{2.5}$ inhibits the chemical formation of ozone through the heterogeneous absorption of $\mathrm{HO}_{2}$ radicals and $\mathrm{NO}_{\mathrm{x}}$. The inhibition of ozone by $\mathrm{PM}_{2.5}$ also causes ozone generation to be more affected by VOC emissions; that is to say, the sensitivity of ozone to reductions in $\mathrm{NO}_{\mathrm{x}}$ emissions is reduced. Therefore, when reducing $\mathrm{NO}_{\mathrm{x}}$ and controlling $\mathrm{PM}_{2.5}$, it is necessary to effectively control VOC emissions to slow down $\mathrm{O}_{3}$ (Li et al., 2019b). These results indicate that the air quality during the COVID lockdown in 2020 was significantly improved compared with that during the post-COVID end to such restrictions in 2021 in the BTT region.

The possible reasons for poorer air quality in the Beijing-Tianjin-Tangshan region from February to March in 2021 are as follows: Firstly, the frequency of dusty weather has increased. Several dusty weather events occurred from February to March, and the dusty days in the BTT region in 2021 exceeded the total of the same period from 2017 to 2020 (Yin et al., 2021). Secondly, meteorological conditions in the BTT region in 2021 were relatively unfavorable compared to the same period in 2020. From February to March, the surface temperature and humidity in 2021 were higher, and the atmospheric temperature inversion intensity was stronger than that of the same period in 2020. In general, the atmospheric diffusion conditions in 2021 were less favorable than in 2020 (Yin et al., 2021). Thirdly, pollutant discharge levels in the BTT region from FebruaryMarch in 2021 were higher than in 2020. In the spring of 2020, economic development was significantly affected by COVID. In 2021, the epidemic was effectively brought under control, the overall economic situation improved, and social and economic activities resumed rapidly after the Spring Festival, leading to an annual increase in pollution emissions. In periods of heavy pollution, it is common for industrial enterprises in the BTT region to fail to implement emission reduction

Table 3. Basic air quality statistics during the COVID outbreak in 2020 (and the same period in 2021) (unit: $\mu \mathrm{g} \mathrm{m}^{-3}\left(\mathrm{CO}\right.$ ( $\left.\mathrm{mg} \mathrm{m}^{-3}\right)$ )).

\begin{tabular}{lllllllll}
\hline Region & Time & $\mathrm{AQI}$ & $\mathrm{PM}_{2.5}$ & $\mathrm{PM}_{10}$ & $\mathrm{SO}_{2}$ & $\mathrm{CO}$ & $\mathrm{NO}_{2}$ & $\mathrm{O}_{3}$ \\
\hline Beijing & 2020 & 75.7 & 42.7 & 59.0 & 4.0 & 0.59 & 24.7 & 89.7 \\
& 2021 & 104.0 & 59.7 & 117.3 & 3.3 & 0.65 & 30.0 & 83.0 \\
Tianjin & 2020 & 79.0 & 48.0 & 69.3 & 8.7 & 0.77 & 34.7 & 93.3 \\
& 2021 & 97.3 & 58.7 & 113.7 & 9.3 & 0.85 & 42.0 & 85.0 \\
Tangshan & 2020 & 83.7 & 51.0 & 92.0 & 18.3 & 1.24 & 41.3 & 89.0 \\
& 2021 & 106.7 & 66.0 & 132.0 & 14.3 & 1.15 & 48.3 & 84.0 \\
BTT & 2020 & 79.4 & 47.2 & 73.4 & 10.3 & 0.87 & 33.6 & 90.7 \\
& 2021 & 102.7 & 61.4 & 121.0 & 9.0 & 0.88 & 40.1 & 84.0 \\
\hline
\end{tabular}


Table 4. Basic statistics revealing the proportions of air quality grades (\%) during the COVID outbreak in 2020 (and the same period in 2021).

\begin{tabular}{llllllll}
\hline Region & Time & I & II & III & IV & V & VI \\
\hline Beijing & 2020 & 36.7 & 46.7 & 7.8 & 4.4 & 4.4 & 0.0 \\
& 2021 & 19.1 & 44.9 & 18.0 & 10.1 & 2.2 & 5.6 \\
Tianjin & 2020 & 26.7 & 47.8 & 21.1 & 2.2 & 2.2 & 0.0 \\
& 2021 & 16.9 & 48.3 & 25.8 & 4.5 & 2.2 & 2.2 \\
\multirow{2}{*}{ Tangshan } & 2020 & 18.9 & 56.7 & 17.8 & 3.3 & 3.3 & 0.0 \\
\multirow{3}{*}{ BTT } & 2021 & 10.1 & 43.8 & 32.6 & 7.9 & 3.4 & 2.2 \\
& 2020 & 27.4 & 50.4 & 15.6 & 3.3 & 3.3 & 0.0 \\
& 2021 & 15.4 & 45.7 & 25.5 & 7.5 & 2.6 & 3.4 \\
\hline
\end{tabular}

measures according to regulations, to reduce emission reduction requirements, and even to evade scrutiny by any means possible.

We also counted the proportion of AQI grades from the COVID lockdown to post-COVID unrestricted era in the BTT region, respectively. It can be seen from Table 4, in the BTT region, from the COVID outbreak in 2020 to the post-COVID era in 2021, the proportions of grades I, II, III, IV, V, and VI were $27.4 \%, 50.4 \%, 15.6 \%, 3.3 \%, 3.3 \%, 0.0 \%$; $15.4 \%, 45.7 \%, 25.5 \%, 7.5 \%, 2.6 \%$, and $3.4 \%$, respectively. The combined proportions of grades I and II during the COVID outbreak 2020 were $77.8 \%$ higher than those in the post-COVID era in 2021, which indicates that the air quality during the COVID outbreak in 2020 was obviously improved compared with that in the post-COVID era in 2021.

The possible reason for this improvement is that during the COVID-19 epidemic, social and economic activities, such as transportation and industrial production activities were dramatically restricted, leading to a rapid reduction in the emission of air pollutants from vehicle exhaust and industrial production.

During the epidemic control period, the significant decrease in human activity, especially the sharp reduction in traffic emissions (more than a $70 \%$ reduction compared with the same period in former years), led to a reduction in $\mathrm{NO}_{x}$ and primary emissions of particulate matter. However, because of the "titration" effect of nitric oxide on ozone and the nonlinear response of ozone formation to nitrogen oxides and volatile organic compounds, this led to a significant increase in the ozone concentration from the Yangtze River Delta to Beijing-Tianjin-Hebei (Huang et al., 2020).

\subsection{Air Quality Changes during the Post-COVID Era in the BTT Region}

We also conducted a statistical analyses of air quality in the BTT region, from May 1 to October 31, 2020-2021, for which the results are shown in Table 5. The average AQI values, and concentrations of $\mathrm{PM}_{2.5}, \mathrm{PM}_{10}, \mathrm{SO}_{2}, \mathrm{CO}, \mathrm{NO}_{2}, \mathrm{O}_{3}$ were, respectively, 97.7, $37.6 \mu \mathrm{g} \mathrm{m}^{-3}, 64.5 \mu \mathrm{g} \mathrm{m}^{-3}, 9.1 \mu \mathrm{g} \mathrm{m}^{-3}$, $0.84 \mathrm{mg} \mathrm{m}^{-3}, 33.8 \mu \mathrm{g} \mathrm{m}^{-3}$, and $128.0 \mu \mathrm{g} \mathrm{m}^{-3}$ during the post-COVID period in 2020 . However, they were, respectively, 83.2, $26.7 \mu \mathrm{g} \mathrm{m}^{-3}, 55.1 \mu \mathrm{g} \mathrm{m}^{-3}, 5.7 \mu \mathrm{g} \mathrm{m}^{-3}, 0.71 \mathrm{mg} \mathrm{m}^{-3}, 26.2 \mu \mathrm{g} \mathrm{m}^{-3}$, and 116.9 $\mu \mathrm{g} \mathrm{m}^{-3}$ during the post-COVID period in 2021 , which is a decline of $14.8 \%, 29.0 \%, 14.6 \%, 22.5 \%$, $37.4 \%, 14.8 \%$, and $8.7 \%$, compared with that in 2020 . It is also worth mentioning that the change in the $\mathrm{O}_{3}$ concentration was consistent with the changes in the other values. It is also worth noting that all the changes in air pollution during the post-COVID era (2020-2021) were consistent. However, these three cities have noteworthy differences, with decreases in the $\mathrm{SO}_{2}$ concentration in Beijing and Tangshan, and increases in Tianjin. These results indicate the air quality during the post-COVID period in 2021 was obviously improved compared with the same period in 2020 in the BTT region.

We also counted the proportions of the AQI grades in the BTT region during the post-COVID era in 2020 (and the same period in 2021), respectively. It can be seen from Table 6, that in the BTT region, during the post-COVID era in 2020-2021, the proportions of grades I, II, III, IV, V, and VI were $15.2 \%, 49.6 \%, 28.1 \%, 6.3 \%, 0.7 \%$, and $0.0 \% ; 23.4 \%, 55.8 \%, 17.4 \%, 2.4 \%, 0.9 \%$, and $0.2 \%$, respectively. The combined proportions of grade I and grade II during post-COVID era in 2021 were $14.3 \%$ higher than those in the same period in 2020, which indicates that the air quality during the post-COVID era in 2021 was obviously improved compared with that in the same period in 2020. 
Table 5. Basic air quality statistics during the post-COVID era in 2020 (and the same period in 2021) (unit: $\mu \mathrm{g} \mathrm{m}^{-3}\left(\mathrm{CO}\left(\mathrm{mg} \mathrm{m}^{-3}\right)\right)$ ).

\begin{tabular}{lllllllll}
\hline Region & Time & $\mathrm{AQI}$ & $\mathrm{PM}_{2.5}$ & $\mathrm{PM}_{10}$ & $\mathrm{SO}_{2}$ & $\mathrm{CO}$ & $\mathrm{NO}_{2}$ & $\mathrm{O}_{3}$ \\
\hline Beijing & 2020 & 84.7 & 33.8 & 53.7 & 3.2 & 0.60 & 26.0 & 122.5 \\
& 2021 & 69.5 & 20.3 & 44.0 & 3.0 & 0.54 & 19.8 & 110.0 \\
Tianjin & 2020 & 90.7 & 38.5 & 60.2 & 7.0 & 0.84 & 32.8 & 131.7 \\
& 2021 & 80.8 & 28.0 & 56.0 & 7.2 & 0.79 & 28.5 & 121.8 \\
\multirow{3}{*}{ Tangshan } & 2020 & 93.0 & 40.5 & 79.7 & 17.0 & 1.07 & 42.5 & 129.8 \\
& 2021 & 81.2 & 31.8 & 65.2 & 6.8 & 0.81 & 30.2 & 118.8 \\
BTT & 2020 & 97.7 & 37.6 & 64.5 & 9.1 & 0.84 & 33.8 & 128.0 \\
& 2021 & 83.2 & 26.7 & 55.1 & 5.7 & 0.71 & 26.2 & 116.9 \\
\hline
\end{tabular}

Table 6. Basic statistics for the proportions of air quality grades (\%) during the post-COVID era in 2020 (and the same period in 2021).

\begin{tabular}{llllllll}
\hline Region & Time & I & II & III & IV & V & VI \\
\hline Beijing & 2020 & 22.8 & 44.0 & 28.8 & 3.3 & 1.1 & 0.0 \\
& 2021 & 37.0 & 47.8 & 13.6 & 1.1 & 0.5 & 0.0 \\
\multirow{3}{*}{ Tianjin } & 2020 & 15.2 & 48.4 & 29.9 & 6.0 & 0.5 & 0.0 \\
& 2021 & 16.8 & 58.7 & 20.7 & 2.7 & 1.1 & 0.0 \\
Tangshan & 2020 & 7.6 & 56.5 & 25.5 & 9.8 & 0.5 & 0.0 \\
\multirow{3}{*}{ BTT } & 2021 & 16.3 & 60.9 & 17.9 & 3.3 & 1.1 & 0.5 \\
& 2020 & 15.2 & 49.6 & 28.1 & 6.3 & 0.7 & 0.0 \\
& 2021 & 23.4 & 55.8 & 17.4 & 2.4 & 0.9 & 0.2 \\
\hline
\end{tabular}

The air quality from May to October 2021 is better than that in the same period in 2020 . The main reasons are as follows. Firstly, Atmospheric diffusion conditions are favorable. Meteorological elements such as wind speed and frequency of north winds in 2021 during the observation period were at good levels compared with 2020, and the horizontal diffusion conditions were also relatively good. At the same time, the precipitation was relatively low, only about half of the same period from 2008 to 2020 (Xue et al., 2020, 2021). The relative humidity is also low, which is not conducive to the generation and transformation of secondary pollutants in $\mathrm{PM}_{2.5}$.

Secondly, the Chinese government has adopted a series of clean air policies and clean air actions. In 2021, China's Ministry of Ecology and Environment announced an air quality improvement goal called the $14^{\text {th }}$ Five-Year Plan. Preliminarily considering 337 cities, $\mathrm{PM}_{2.5}$ is expected to decrease by $10 \%$ annually, and the number of excellent days is expected to increase to $87.5 \%$. The Chinese government has carried out tracking research on the "one city, one policy" for the purpose of coordinated prevention and control of fine particulate matter and ozone pollution, while focusing on pollution prevention and control and, jointly promoting the financing of major ecological and environmental protection projects and, improving and optimizing the law enforcement leading to ecological and environmental protection.

The Chinese government has vigorously promoted the adjustment of the industrial structure, actively promoting the optimization of the energy structure and accelerating adjustments to the transportation sector. It has also promoted the remediation of non-point source pollution and promoted in-depth emission treatment of industrial enterprises. It has also increased collaborative emission reductions in VOCs and NOx, strengthened the collaborative control of $\mathrm{PM}_{2.5}$ and ozone $\left(\mathrm{O}_{3}\right)$, and promoted the synergy of pollution reduction and carbon reduction.

\subsection{Monthly Variations in Air Quality}

As shown in Fig. 3, in the BTT region during January-October 2020, the average AQI values were $116,91,69,79,84,117,104,86,64$, and 82 , respectively, while those during JanuaryOctober 2021 averaged 83, 96, 139, 73, 86, 87, 79, 80, 65, and 65, respectively, which were $-28.7 \%, 5.5 \%, 102.4 \%,-7.2 \%, 2.4 \%,-25.4 \%,-23.7 \%,-6.6 \%, 2.6 \%$, and $-21.1 \%$ higher than those during January-October 2020, respectively. 


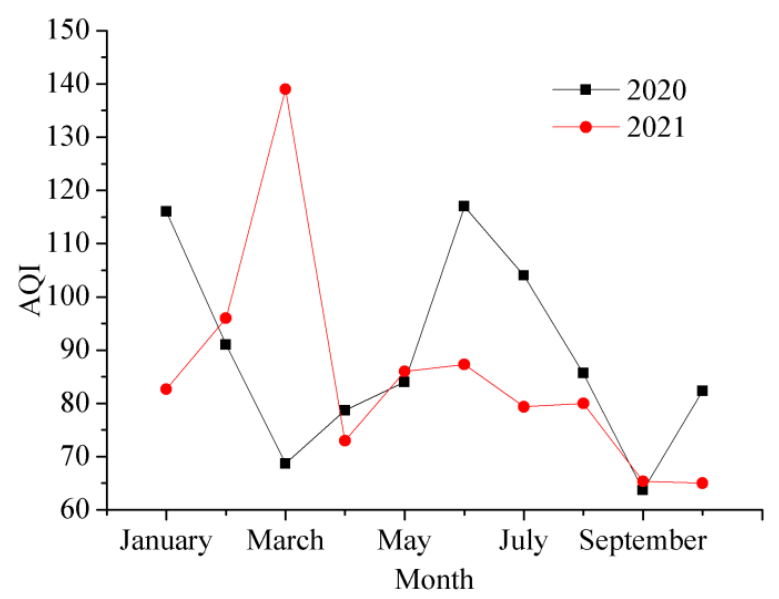

Fig. 3. Comparison of monthly variations in the AQI in the Beijing-Tianjin-Tangshan region from 2020 to 2021.

Atmospheric particulate matter (PM) is a mixture of dust, inorganic ions, organic components, etc. $\mathrm{PM}_{2.5}$ refers to a PM concentration of less than $2.5 \mu \mathrm{m}$. It is easily accumulated in the human airway and affects human health (Zhang and Routledge, 2020). $\mathrm{PM}_{10}$ refers to a PM concentration of less than $10 \mu \mathrm{m}$. It is mainly derived from vehicle exhaust, fuel combustion, industrial emissions, and dust entrainment (Wang et al., 2020b). Artificially made sulfur dioxide $\left(\mathrm{SO}_{2}\right)$ is mainly derived from oil, coal, and petroleum (Ebrahimi and Qaderi, 2021). Carbon monoxide (CO) is mainly produced by incomplete burning of fossil and biomass fuels (Zhao et al., 2020). Nitrogen dioxide $\left(\mathrm{NO}_{2}\right)$ mainly comes from the combustion of fossil fuels, industrial emissions, and traffic emissions (Zhao et al., 2020). Ozone $\left(\mathrm{O}_{3}\right)$ is a secondary pollutant formed in the atmosphere because of reactions between other pollutants emitted mainly by power plants, industries, and automobiles (Zoran et al., 2020). $\mathrm{O}_{3}$ mainly originates from the photochemical formation of volatile organic compounds (VOCs) and $\mathrm{NO}_{\mathrm{x}}$, and ozone precursors (VOCs and $\mathrm{NO}_{\mathrm{x}}$ ) mostly derived from fuel combustion and industrial sources. VOC emissions also come from natural sources. $\mathrm{HO}_{\mathrm{x}}$ mainly comes from photochemical oxidation of water vapor and photolysis of hydroxyl groups. Therefore, ozone pollution is most serious in summer (Li et al., 2019b).

As shown in Fig. 4(a), in the BTT region during January-October 2020, the $\mathrm{PM}_{2.5}$ concentrations averaged $86,64,49,50,46,50,45,36,28$, and $50 \mu \mathrm{g} \mathrm{m}^{-3}$, respectively, while those during January-October 2021 averaged 49, 66, 79, 40, 32, 26, 21, 22, 22, and $37 \mu \mathrm{g} \mathrm{m}^{-3}$, respectively, which were $-43.2 \%, 2.6 \%, 61.2 \%,-20.7 \%,-31.2 \%,-47.0 \%,-53.7 \%,-38.5 \%,-20.2 \%$, and $-26.7 \%$ higher than those during January-October 2020, respectively.

As shown in Fig. 4(b), from January-October 2020, the $\mathrm{PM}_{10}$ concentrations averaged 103, 73, $69,79,69,78,58,50,50,47$, and $85 \mathrm{~g} \mathrm{~m}^{-3}$, respectively, while those from January-October 2021 averaged $96,100,174,89,86,53,38,44,46$, and $64 \mu \mathrm{g} \mathrm{m}^{-3}$, respectively, which were $-6.8 \%$, $37.0 \%, 153.9 \%, 12.7 \%, 24.0 \%,-31.6 \%,-35.4 \%,-12.1 \%,-2.8 \%$, and $-24.4 \%$ higher than those from January-October 2020, respectively.

As shown in Fig. 4(c), from January-October 2020, the $\mathrm{SO}_{2}$ concentrations averaged 16, 11, 9, $11,10,11,8,7,8$, and $9 \mu \mathrm{g} \mathrm{m}^{-3}$, respectively, while those from January-October 2021 averaged $11,11,8,8,6,6,4,5,6$, and $7 \mu \mathrm{g} \mathrm{m}^{-3}$, respectively, which were $-31.3 \%,-3.0 \%,-10.7 \%,-25.0 \%$, $-36.7 \%,-47.1 \%,-48.0 \%,-36.4 \%,-25.0 \%$, and $-28.6 \%$ higher than those from January-October 2020 , respectively.

As shown in Fig. 4(d), from January-October 2020, the CO concentrations averaged 1.47, 1.17, $0.73,0.69,0.81,0.87,0.85,0.89,0.82$, and $0.78 \mathrm{mg} \mathrm{m}^{-3}$, respectively, while those from JanuaryOctober 2021 averaged 1.03, 1.08, 0.92,0.64, 0.59, 0.73,0.70,0.76,0.80, and $0.70 \mathrm{mg} \mathrm{m}^{-3}$, respectively, which were $-29.9 \%,-7.4 \%, 25.3 \%,-7.0 \%,-27.3 \%,-15.9 \%,-17.1 \%,-15.2 \%,-1.8 \%$, and $-11.0 \%$ higher than those from January-October 2020, respectively.

As shown in Fig. 4(e), from January-October 2020, the $\mathrm{NO}_{2}$ concentrations averaged 54, 33, $35,33,32,31,27,28,35$, and $50 \mu \mathrm{g} \mathrm{m}^{-3}$, respectively, while those from January-October 2021 average $44,39,45,36,26,25,17,22,27$, and $41 \mu \mathrm{g} \mathrm{m}^{-3}$, respectively, which were $-18.6 \%, 19.4 \%$, 

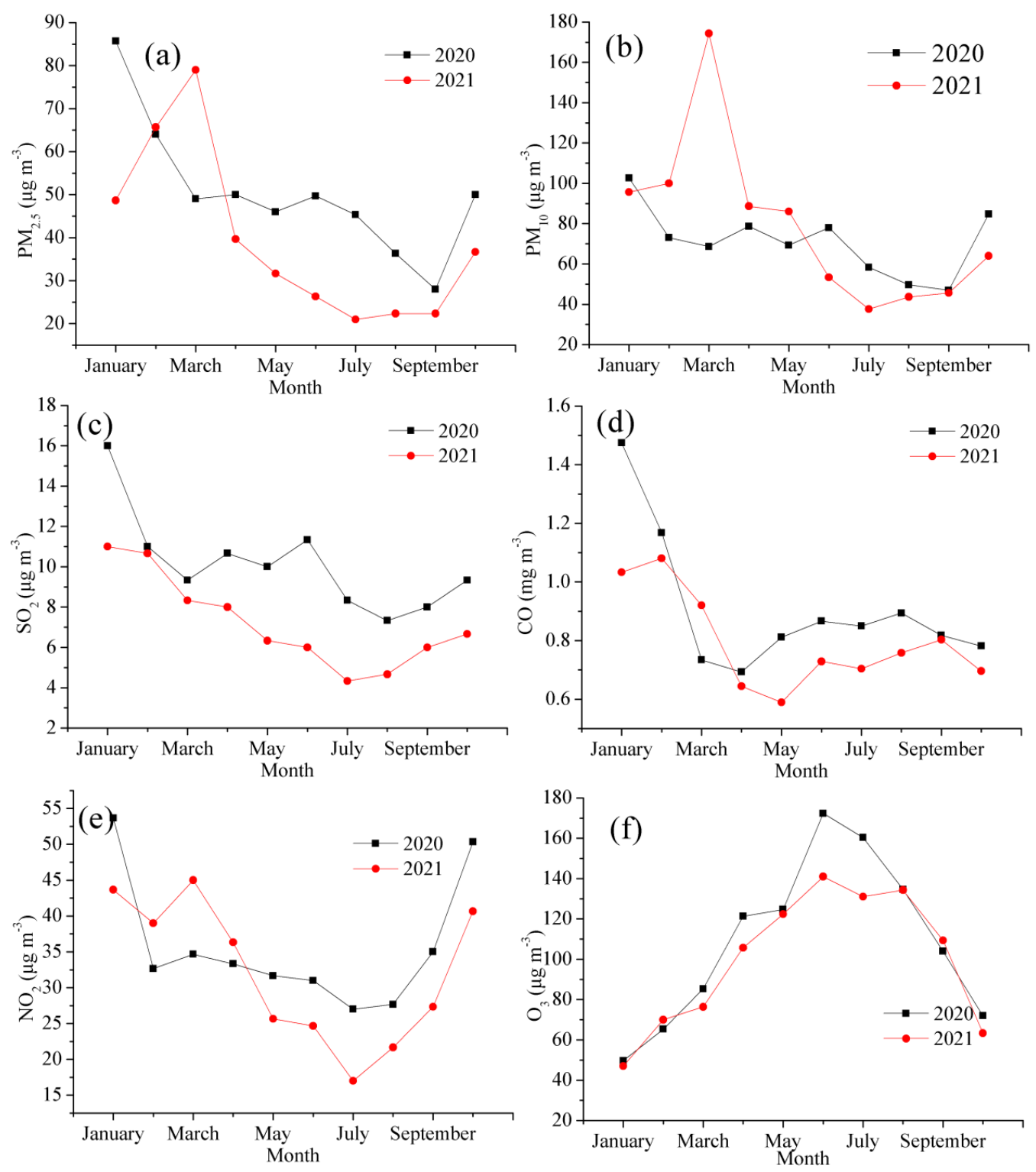

Fig. 4. Comparison of monthly variations in air pollutant concentrations in the Beijing-TianjinTangshan region from 2020 to 2021.

$29.8 \%, 9.0 \%,-18.9 \%,-20.4 \%,-37.0 \%,-21.7 \%,-21.9 \%$, and $-19.2 \%$ higher than those from January-October 2020, respectively.

As shown in Fig. 4(f), from January-October 2020, the $\mathrm{O}_{3}$ concentrations averaged 50, 65, 85, $121,125,172,160,135,104$, and $72 \mu \mathrm{g} \mathrm{m}^{-3}$, respectively, while those from January-October 2021 averaged $47,70,76,106,122,141,131,134,109$, and $63 \mu \mathrm{g} \mathrm{m}{ }^{-3}$, respectively, which were $-5.4 \%$, $7.1 \%,-10.5 \%,-12.9 \%,-1.9 \%,-18.2 \%,-18.3 \%,-0.2 \%, 5.1 \%$, and $-12.0 \%$ higher than those for the period January-October 2020, respectively.

Especially in March 2021, the average AQI values and concentrations of $\mathrm{PM}_{2.5}$, and $\mathrm{PM}_{10}$ were $102.4 \%, 61.2 \%$, and $153.9 \%$ higher than those in 2020, respectively. Those from April to October 2021 were lower than those from April to October 2020, except for the AQI values in May and September, $\mathrm{PM}_{10}$ in April-May, $\mathrm{NO}_{2}$ in April, and $\mathrm{O}_{3}$ in September.

These results indicate that the air quality from February-April 2021 was clearly worse than that in 2020, but the air quality from May-October 2021 was significantly better than that in 2020. The improvements in air quality from February-April 2020 were attributed to epidemic prevention, which resulted in lowered transportation and industrial emissions. However, the improvement of air quality from May-October 2021 was attributed to clean air policies. 

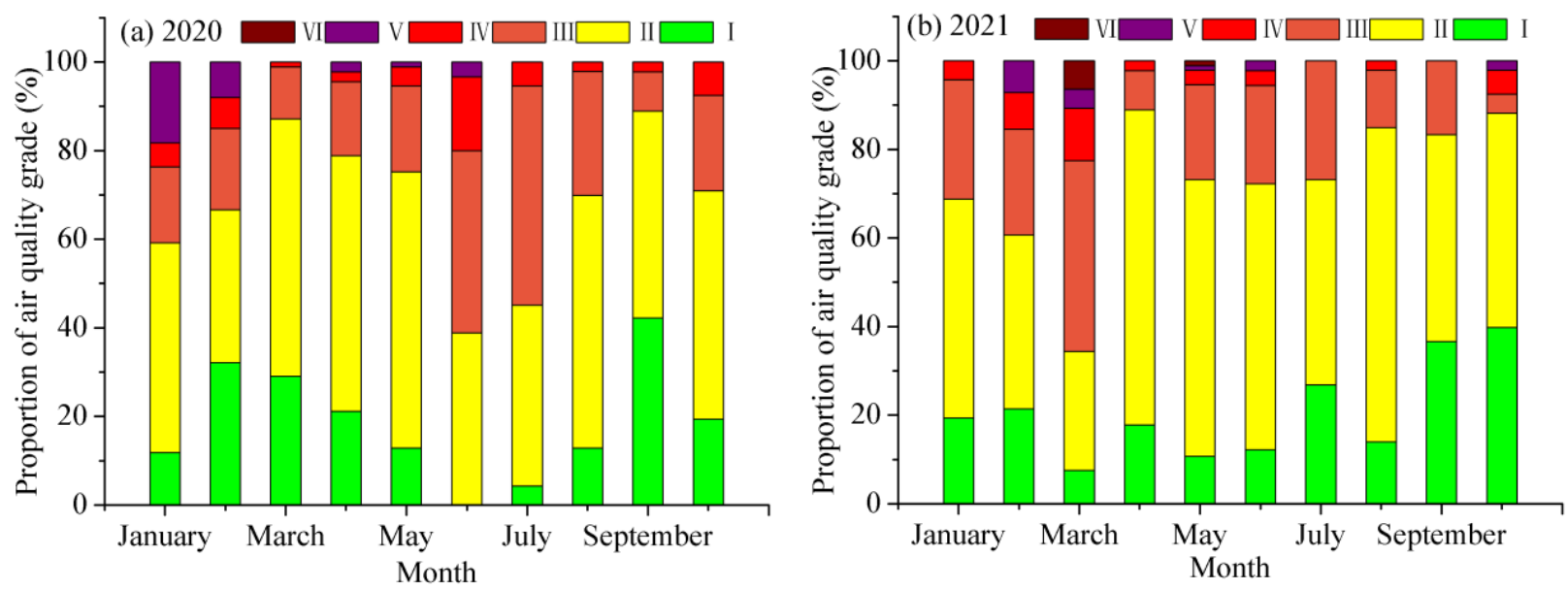

Fig. 5. Monthly changes in the proportions of air quality grades in the Beijing-Tianjin-Tangshan region in 2020 and 2021.

We also calculated the AQI grades in the BTT region from January-October 2020 and those for 2021, respectively. As shown in Fig. 5, in January 2020, the proportions of grades I, II, III, IV, V, and VI were $11.8 \%, 47.3 \%, 17.2 \%, 5.4 \%, 18.3 \%$, and $0.0 \%$, respectively. But those in 2021 were 19.4\%, $49.5 \%, 26.9 \%, 4.3 \%, 0.0 \%$, and $0.0 \%$, respectively. From January 2020 to January 2021, the combined proportions of grade I and grade II increased from $59.1 \%$ to $68.8 \%$, but the combined proportions of grades IV, V, and VI increased from $40.9 \%$ to $31.2 \%$, which indicates that the air quality had greatly improved.

In February 2020, the proportions of grades I, II, III, IV, V, and VI were 32.2\%, 34.5\%, 18.4\%, $6.9 \%, 8.0 \%$, and $0.0 \%$, respectively. However, in February 2021, the proportions of AQI grades I, II, III, IV, V, and VI were $21.4 \%, 39.3 \%, 23.8 \%, 8.3 \%, 7.1 \%$, and $0.0 \%$, respectively. From February 2020 to February 2021, the combined proportions of grade I and grade II decreased from $66.7 \%$ to $60.7 \%$, but the combined proportions of grades III, IV, V, and VI increased from $33.3 \%$ to $39.3 \%$, which indicates that the air quality had dramatically deteriorated during that period.

It can be seen that from March to October 2020, the combined proportions of grade I and grade II were $87.1 \%, 78.9 \%, 75.3 \%, 38.9 \%, 45.2 \%, 69.9 \%, 88.9 \%$, and $71.0 \%$, respectively. However, from March to October 2021, the combined proportions of grade I and grade II were $34.4 \%, 88.9 \%, 73.1 \%, 72.2 \%, 73.1 \%, 84.9 \%, 83.3 \%$, and $88.2 \%$, respectively. It can be seen that from March 2020-2021 to October 2020-2021, the combined proportions of grade I and grade II increased by $-52.7 \%, 10.0 \%,-2.2 \%, 33.3 \%, 28.0 \%, 15.1 \%,-5.6 \%$ and $17.2 \%$, respectively, while the combined proportions of grades III, IV, V, and VI increased by $52.7 \%,-10.0 \%, 2.2 \%,-33.3 \%$, $-28.0 \%,-15.1 \%, 5.6 \%$, and $-17.2 \%$, which indicates that the air quality from April-October 2021 dramatically improved, but the air quality in March 2021 dramatically deteriorated.

\section{CONCLUSIONS}

Air quality has markedly changed from the COVID to post-COVID era in the Beijing-TianjinTangshan region in China. The AQI values and concentrations of $\mathrm{PM}_{2.5}$, and $\mathrm{PM}_{10}$ in the $\mathrm{BTT}$ region from February-April 2021 were respectively 29.2\%, 30.1\%, and 64.8\% higher than those in 2020. However, the average $\mathrm{AQI}$ values and concentrations of $\mathrm{PM}_{2.5}, \mathrm{PM}_{10}, \mathrm{SO}_{2}, \mathrm{CO}, \mathrm{NO}_{2}$, and $\mathrm{O}_{3}$ from May-October 2021 were respectively $14.8 \%, 29.0 \%, 14.6 \%, 22.5 \%, 37.4 \%, 14.8 \%$, and $8.7 \%$ lower than those in 2020.

It is expected that the implementation of active clean air policies will lead to remarkable improvements in air quality. Despite the remarkable air quality improvements introduced by the action plan, air pollution in the BTT region remains severe. On September 22, 2021, the World Health Organization (WHO) issued global Air Quality Guidelines (AQG2021). Air pollutant concentrations in the BTT region remain higher than the AQG.

The COVID-19 epidemic has had an important impact on the air pollution in the Beijing-TianjinTangshan region in unprecedented ways. Reduction of social and economic activities plays a very 
important role in improving air quality. This study is helpful to understand the significance of limiting human activities in an effort to reduce environmental pollutants.

The COVID-19 outbreak caused unprecedented artificial emission reductions from transportation and manufacturing and the subsequent city lockdowns. This offered a unique opportunity to estimate the interaction between emissions, chemistry, and meteorology. This study was an attempt to estimate the influence of the COVID-19 containment measures on unexpected air pollutants in the Beijing-Tianjin-Tangshan region. A more complete estimate would take into account other factors, e.g., meteorological factors, through utilization of chemical transport models in which emissions would be kept at their original grade, where variations in concentration are only caused by variations in emergency emissions due to an emergency. Because the COVID-19 pandemic is still continuing at the global level, future work is urgently needed to identify the causal relationship between air pollution and COVID-19.

The Chinese government has put forward a goal of a carbon peak and carbon neutralization, and has issued an action plan for reaching the carbon peak by 2030. During the $14^{\text {th }}$ Five-Year Plan for the National Economic and Social Development of China, the Chinese government will collaboratively control air pollutants and greenhouse gas emissions while, promoting four structural adjustments in the industry, energy, transportation, and land use.

\section{ACKNOWLEDGMENTS}

This work was supported by the NSFC (41572150, 41472162, 41702373), Shandong Social Sciences Planning Research Program (18CKPJ34), Shandong Province Higher Educational Humanities and Social Science Program (J18RA196), and State Key Laboratory of Loess and Quaternary Geology Foundation (SKLLQG1907). The authors thank the editor and anonymous reviewers for their valuable help.

\section{REFERENCES}

Bao, R., Zhang, A. (2020). Does lockdown reduce air pollution? Evidence from 44 cities in northern China. Sci. Total Environ. 731, 139052. https://doi.org/10.1016/j.scitotenv.2020.139052

Chauhan, A., Singh, R.P. (2020). Decline in $\mathrm{PM}_{2.5}$ concentrations over major cities around the world associated with COVID-19. Environ. Res. 187, 109634. https://doi.org/10.1016/j.envres. 2020.109634

Ebrahimi, M., Qaderi, F. (2021). Determination of the most effective control methods of $\mathrm{SO}_{2}$ pollution in tehran based on adaptive neuro-fuzzy inference system. Chemosphere 263, 128002. https://doi.org/10.1016/j.chemosphere.2020.128002

Gao, C., Li, S., Liu, M., Zhang, F., Achal, V., Tu, Y., Zhang, S., Cai, C. (2021). Impact of the COVID-19 pandemic on air pollution in Chinese megacities from the perspective of traffic volume and meteorological factors. Sci. Total Environ. 773, 145545. https://doi.org/10.1016/j.scitotenv.202 1.145545

Gautam, S. (2020). COVID-19: Air pollution remains low as people stay at home. Air Qual. Atmos. Health 13, 853-857. https://doi.org/10.1007/s11869-020-00842-6

Guo, Q., He, Z., Li, S., Li, X., Meng, J., Hou, Z., Liu, J., Chen, Y. (2020). Air pollution forecasting using artificial and wavelet neural networks with meteorological conditions. Aerosol Air Qual. Res. 20, 1429-1439. https://doi.org/10.4209/aaqr.2020.03.0097

Guo, Q., He, Z. (2021). Prediction of the confirmed cases and deaths of global COVID-19 using artificial intelligence. Environ. Sci. Pollut. Res. 28, 11672-11682. https://doi.org/10.1007/s11356020-11930-6

He, G., Pan, Y., Tanaka, T. (2020). The short-term impacts of COVID-19 lockdown on urban air pollution in China. Nat. Sustainability 3, 1005-1011. https://doi.org/10.1038/s41893-0200581-y

Huang, X., Ding, A., Gao, J., Zheng, B., Zhou, D., Qi, X., Tang, R., Wang, J., Ren, C., Nie, W., Chi, X., Xu, Z., Chen, L., Li, Y., Che, F., Pang, N., Wang, H., Tong, D., Qin, W., Cheng, W., et al. (2021). Enhanced secondary pollution offset reduction of primary emissions during COVID-19 lockdown in China. Natl. Sci. Rev. 8, nwaa137. https://doi.org/10.1093/nsr/nwaa137 
Kanniah, K.D., Kamarul Zaman, N.A.F., Kaskaoutis, D.G., Latif, M.T. (2020). COVID-19's impact on the atmospheric environment in the southeast Asia region. Sci. Total Environ. 736, 139658. https://doi.org/10.1016/j.scitotenv.2020.139658

Lal, P., Kumar, A., Kumar, S., Kumari, S., Saikia, P., Dayanandan, A., Adhikari, D., Khan, M.L. (2020). The dark cloud with a silver lining: Assessing the impact of the sars COVID-19 pandemic on the global environment. Sci. Total Environ. 732, 139297. https://doi.org/10.1016/j.scitotenv.2020. 139297

Le, T., Wang, Y., Liu, L., Yang, J., Yung, Y.L., Li, G., Seinfeld, J.H. (2020). Unexpected air pollution with marked emission reductions during the COVID-19 outbreak in China. Science 369, 702706. https://doi.org/10.1126/science.abb7431

Li, H., Ma, Y., Duan, F., Zhu, L., Ma, T., Yang, S., Xu, Y., Li, F., Huang, T., Kimoto, T., Zhang, Q., Tong, D., Wu, N., Hu, Y., Huo, M., Zhang, Q., Ge, X., Gong, W., He, K. (2021). Stronger secondary pollution processes despite decrease in gaseous precursors: A comparative analysis of summer 2020 and 2019 in Beijing. Environ. Pollut. 279, 116923. https://doi.org/10.1016/j.envpol.2021. 116923

Li, K., Jacob, D.J., Liao, H., Shen, L., Zhang, Q., Bates, K.H. (2019a). Anthropogenic drivers of 20132017 trends in summer surface ozone in China. PNAS 116, 422-427. https://doi.org/10.1073/ pnas.1812168116

Li, K., Jacob, D.J., Liao, H., Zhu, J., Shah, V., Shen, L., Bates, K.H., Zhang, Q., Zhai, S. (2019b). A twopollutant strategy for improving ozone and particulate air quality in China. Nat. Geosci. 12, 906-910. https://doi.org/10.1038/s41561-019-0464-x

Mahato, S., Pal, S., Ghosh, K.G. (2020). Effect of lockdown amid COVID-19 pandemic on air quality of the megacity Delhi, India. Sci. Total Environ. 730, 139086. https://doi.org/10.1016/j.scitoten v.2020.139086

Muhammad, S., Long, X., Salman, M. (2020). COVID-19 pandemic and environmental pollution: A blessing in disguise? Sci. Total Environ. 728, 138820. https://doi.org/10.1016/j.scitotenv.2020. 138820

Otmani, A., Benchrif, A., Tahri, M., Bounakhla, M., Chakir, E.M., El Bouch, M., Krombi, M.h. (2020). Impact of COVID-19 lockdown on $\mathrm{PM}_{10}, \mathrm{SO}_{2}$ and $\mathrm{NO}_{2}$ concentrations in Salé City (Morocco). Sci. Total Environ. 735, 139541. https://doi.org/10.1016/j.scitotenv.2020.139541

Shakoor, A., Chen, X., Farooq, T.H., Shahzad, U., Ashraf, F., Rehman, A., Sahar, N. e., Yan, W. (2020). Fluctuations in environmental pollutants and air quality during the lockdown in the USA and China: Two sides of COVID-19 pandemic. Air Qual Atmos Health 13, 1335-1342. https://doi.org/10.1007/s11869-020-00888-6

Steinfeld, J.I. (1998). Atmospheric chemistry and physics: From air pollution to climate change. Environ.: Sci. Policy Sustainable Dev. 40, 26. https://doi.org/10.1080/00139157.1999.10544295

Wang, J., Lei, Y., Chen, Y., Wu, Y., Ge, X., Shen, F., Zhang, J., Ye, J., Nie, D., Zhao, X., Chen, M. (2021). Comparison of air pollutants and their health effects in two developed regions in China during the COVID-19 pandemic. J. Environ. Manage. 287, 112296. https://doi.org/10.1016/j.jenvman. 2021.112296

Wang, P., Chen, K., Zhu, S., Wang, P., Zhang, H. (2020a). Severe air pollution events not avoided by reduced anthropogenic activities during COVID-19 outbreak. Resour. Conserv. Recycl. 158, 104814. https://doi.org/10.1016/j.resconrec.2020.104814

Wang, Y., Yuan, Y., Wang, Q., Liu, C., Zhi, Q., Cao, J. (2020b). Changes in air quality related to the control of coronavirus in China: Implications for traffic and industrial emissions. Sci. Total Environ. 731, 139133. https://doi.org/10.1016/j.scitotenv.2020.139133

Wu, J., Bei, N., Hu, B., Liu, S., Wang, Y., Shen, Z., Li, X., Liu, L., Wang, R., Liu, Z., Cao, J., Tie, X., Molina, L.T., Li, G. (2020). Aerosol-photolysis interaction reduces particulate matter during wintertime haze events. PNAS 117, 9755-9761. https://doi.org/10.1073/pnas.1916775117

Xu, K., Cui, K., Young, L.H., Hsieh, Y.K., Wang, Y.F., Zhang, J., Wan, S. (2020a). Impact of the COVID19 event on air quality in central China. Aerosol Air Qual. Res. 20, 915-929. https://doi.org/10. 4209/aaqr.2020.04.0150

Xu, K., Cui, K., Young, L.H., Wang, Y.F., Hsieh, Y.K., Wan, S., Zhang, J. (2020b). Air quality index, indicatory air pollutants and impact of COVID-19 event on the air quality near central China. Aerosol Air Qual. Res. 20, 1204-1221. https://doi.org/10.4209/aaqr.2020.04.0139

Xue, B., Wang, G., Xiao, J., Helman, D., Sun, W., Wang, J., Liu, T. (2020). Global convergence but 
regional disparity in the hydrological resilience of ecosystems and watersheds to drought. J. Hydrol. 591, 125589. https://doi.org/10.1016/j.jhydrol.2020.125589

Xue, B., Helman, D., Wang, G., Xu, C.Y., Xiao, J., Liu, T., Wang, L., Li, X., Duan, L., Lei, H. (2021). The low hydrologic resilience of Asian water tower basins to adverse climatic changes. Adv. Water Resour. 155, 103996. https://doi.org/10.1016/j.advwatres.2021.103996

Yin, Z., Wan, Y., Zhang, Y., Wang, H. (2021). Why super sandstorm 2021 in North China. Natl. Sci. Rev. nwab165. https://doi.org/10.1093/nsr/nwab165

Zhang, S., Routledge, M.N. (2020). The contribution of $\mathrm{PM}_{2.5}$ to cardiovascular disease in China. Environ. Sci. Pollut. Res. 27, 37502-37513. https://doi.org/10.1007/s11356-020-09996-3

Zhang, Y., Ma, Z., Gao, Y., Zhang, M. (2021). Impacts of the meteorological condition versus emissions reduction on the $\mathrm{PM}_{2.5}$ concentration over Beijing-Tianjin-Hebei during the COVID-19 lockdown. Atmos. Oceanic Sci. Lett. 14, 100014. https://doi.org/10.1016/j.aosl.2020.100014

Zhao, Z., Qin, J., He, Z., Li, H., Yang, Y., Zhang, R. (2020). Combining forward with recurrent neural networks for hourly air quality prediction in northwest of China. Environ. Sci. Pollut. Res. 27, 28931-28948. https://doi.org/10.1007/s11356-020-08948-1

Zoran, M.A., Savastru, R.S., Savastru, D.M., Tautan, M.N. (2020). Assessing the relationship between ground levels of ozone $\left(\mathrm{O}_{3}\right)$ and nitrogen dioxide $\left(\mathrm{NO}_{2}\right)$ with coronavirus (COVID-19) in Milan, Italy. Sci. Total Environ. 740, 140005. https://doi.org/10.1016/j.scitotenv.2020.140005 